\section{Atrioventricular canal defect and associated genetic disorders: new insights into polydactyly syndromes}

\author{
M. Cristina Digilio,' Paolo Versacci, ${ }^{2}$ \\ Francesca Lepri, ${ }^{1}$ Anwar Baban, ${ }^{1}$ \\ Bruno Dallapiccola, ${ }^{1}$ Bruno Marino ${ }^{2}$ \\ ${ }^{1}$ Medical Genetics, Pediatric Cardiology \\ and Cytogenetics, Bambino Gesù \\ Pediatric Hospital, IRCCS; ${ }^{2}$ Department \\ of Pediatrics, Pediatric Cardiology, \\ University La Sapienza, Rome, Italy
}

\section{Abstract}

Atrioventricular canal defect (AVCD) is a common congenital heart defect (CHD), representing $7.4 \%$ of all cardiac malformations, considered secondary to an extracellular matrix anomaly. The AVCD is associated with extracardiac defects in about $75 \%$ of the cases. In this review we analyzed different syndromic AVCDs, in particular those associated with polydactyly disorders, which show remarkable genotype-phenotype correlations. Chromosome imbalances more frequently associated with AVCD include Down syndrome, deletion 8p23 and deletion 3p25, while mendelian disorders include Noonan syndrome and related RASopathies, several polydactyly syndromes, CHARGE and 3C (cranio-cerebello-cardiac) syndrome. The complete form of AVCD is prevalent in patients with chromosomal imbalances. Additional cardiac defects are found in patients affected by chromosomal imbalances different from Down syndrome. Left-sided obstructive lesions are prevalently found in patients with RASopathies. Patients with deletion 8p23 often display AVCD with tetralogy of Fallot or with pulmonary valve stenosis. Tetralogy of Fallot is the only additional cardiac defect found in patients with Down syndrome and AVCD. On the other hand, the association of AVCD and tetralogy of Fallot is also quite characteristic of CHARGE and 3C syndromes. Heterotaxia defects, including common atrium and anomalous pulmonary venous return, occur in patients with AVCD associated with polydactyly syndromes (Ellis-van Creveld, short rib polydactyly, oral-facial-digital, Bardet-Biedl, and Smith-Lemli-0pitz syndromes). The initial clinical evidence of anatomic similarities between AVCD and heterotaxia in polydactyly syndromes was corroborated and explained by experimental studies in transgenic mice. These investigations have suggested the involvement of the Sonic Hedgehog pathway in syndromes with postaxial polydactyly and heterotaxia, and ciliary dysfunction was detected as pathomechanism for these disorders. Anatomic differences in AVCD in the different groups are probably due to different genetic causes.

\section{Introduction}

Atrioventricular canal defect (AVCD) is a common congenital heart defect (CHD), representing $7.4 \%$ of all cardiac defects. ${ }^{1}$ This malformation is characterized by a spectrum of anomalies of the atrioventricular valves, atrial and ventricular septa. In the complete form a single common atrioventricular valve is found together with an atrial septal defect (ostium primum), and a confluent posterior ventricular septal defect in the inlet portion of the ventricular septum. In the partial form, two separate right and left atrioventricular valves are found with a cleft of the mitral valve, an atrial septal defect (ostium primum), and no ventricular septum communication. According to Clark et al., ${ }^{2}$ this malformation is classified in the group of defects of the extracellular matrix.

AVCD is associated with extracardiac malformations in about $75 \%$ of the cases. ${ }^{3,4}$ Four major groups can be distinguished, including patients with Down syndrome (45\%), or other syndromes (15\%), or heterotaxia (15\%), or a non-syndromic AVCD (25\%). ${ }^{4}$

In this review we analyzed the various forms of AVCD, with particular attention to polydactyly syndromes, which display remarkable genotype-phenotype correlations.

\section{Atrioventricular canal defect and \\ Down syndrome}

Down syndrome, due to trisomy 21 , is the genetic disorder more frequently associated with AVCD. Clinical manifestations include facial anomalies, mental retardation, CHD, and gastrointestinal malformations (Table 1). ${ }^{5}$ CHD occur in about $40-50 \%$ of these patients, and cardiac care can prevent morbidity and mortality due to congestive heart failure and pulmonary vascular disease. The anatomic patterns of AVCD and the associated cardiac malformations are quite distinct in this syndrome. The complete form of AVCD is the most frequent type of CHD associated with trisomy 21, and about $70 \%$ of all children with complete AVCD display this aneuploidy. Children with Down syndrome show a simple form of AVCD, which is usually complete, and rarely associated with additional cardiac anomalies (with the only notable exception of tetralogy of Fallot) (Table 2). Left-sided obstructive lesions are significantly rare in children with AVCD and Down syndrome compared to patients with AVCD without Down syndrome.,46-10 Accord ingly, some types of situs abnormalities such
Correspondence: M. Cristina Digilio, Medical Genetics, Bambino Gesù Hospital, IRCCS, Piazza S. Onofrio 4,00165 , Rome, Italy.

Tel: +39.06-68592227 - Fax: +39.06.68592004.

E-mail: mcristina.digilio@opbg.net

Key words: atrioventricular canal defect, chromosomal syndrome, RASopathies, polydactyly, laterality defect.

Received for publication: 1 July 2011 . Accepted for publication: 8 July 2011.

This work is licensed under a Creative Commons Attribution NonCommercial 3.0 License (CC BYNC 3.0).

CCopyright M.C. Digilio et al., 2011

Licensee PAGEPress, Italy

Cardiogenetics 2011; 1:e7

doi:10.4081/cardiogenetics.2011.e7

as l-loop of the ventricles, atresia of the atrioventricular valves and transposition of the great arteries are virtually absent in subjects with Down syndrome. ${ }^{9}$

It has been shown that surgical correction of AVCD in individuals with Down syndrome results in lower mortality and morbidity rates, compared to the children without trisomy $21 .{ }^{11}$

The relationship between AVCD and Down syndrome is still unclear. A number of genes located in the CHD critical region on chromosome 21 have been considered pathogenetically related to $A V C D$, including DSCAM, ${ }^{12}$ COL6A1, ${ }^{13}$ and DSCR1. ${ }^{14}$

\section{Atrioventricular canal defect and chromosomal anomalies}

\section{Deletion 8p23}

Terminal deletion of the short arm of chromosome 8 (del8p23) is the second chromosomal anomaly more frequently associated with AVCD. ${ }^{4}$ The number of patients with this anomaly has increased progressively in parallel with the improved ability of molecular and cytogenetic techniques to recognize small imbalances. Clinical characteristics of the syndrome include microcephaly, mental retardation, CHD, hypospadia, and facial anomalies (Table 1). ${ }^{15-19}$ Cardiac malformations are present in two third of the patients, ${ }^{18}$ and AVCD is found in about $40 \%$ of the cases. In general, the AVCD is complete, and often associated with pulmonary valve stenosis (Table 2). ${ }^{17,18,20-22}$ The GATA4 gene, which maps to the $8 \mathrm{p} 23.1$ region, and is often deleted in these patients, is candidate to CHD in del8p23, being expressed in the developing heart. ${ }^{22-24}$ Other genes within this critical region could contribute to these defects, ${ }^{24}$ since GATA4 is not invariably deleted in subjects with CHD and del8p23.1. However, 
impaired expression of GATA4 gene secondary to a positional effect should also be considered.

Dextrocardia, abnormalities of the pulmonary and systemic vein returns, common atrium, pulmonary stenosis, single ventricle, and transposition of the great arteries are found in a number of del8p23 patients,,$^{18}$ suggesting that monosomy of the short arm of chromosome 8 is responsible for laterality defects in a subset of these subjects.

\section{Deletion 3p25}

Deletion 3p25 syndrome can be associated with AVCD. ${ }^{25-27}$ Clinical features of this syndrome include mental retardation, microcephaly, facial anomalies (ptosis, telecanthus and micrognathia) (Table 1). Differences in proximal breakpoints lead to clinical variability, including CHD, postaxial polydactyly, renal anomalies, gastrointestinal malformations, and cleft palate. CHD, including AVCD, is found in about one-third of del3p25 patients. ${ }^{27}$ Complete AVCD has been reported in at least one individual. ${ }^{28} \mathrm{~A}$ cell adhesion molecule, coded by CRELD1 gene, has been identified as a likely candidate for AVCD, based on its map position on chromosome 3p25 and the expression pattern in the developing heart. ${ }^{29}$ Analysis of the CRELD1 gene in patients with non-syndromic partial AVCD has identified heterozygous missence mutations in about $6 \%$ of the cases, associated with heterotaxia in at least one of them. ${ }^{30}$

\section{Atrioventricular canal defect and mendelian disorders}

RASopathies (Noonan syndrome and related disorders)

Noonan Syndrome (NS) and related disorders including LEOPARD, Noonan-like with loose anagen hair, Cardio-Facio-Cutaneous and Costello syndromes (the so-called RASopathies) are caused by mutations affecting several genes participating in the RASMAP kinase (MAPK) signaling pathway. ${ }^{31-33}$ Clinical features include facial anomalies, CHD, growth retardation, ectodermal and skeletal defects, and variable cognitive deficits (Table 1). CHD is found in about $65-85 \%$ of the cases, depending on the mutated genes. AVCD is the third most frequent CHD in Noonan syndrome after pulmonary valve stenosis and hypertrophic cardiomyopathy, ${ }^{34,35}$ and can be also a feature of LEOPARD syndrome. ${ }^{36,37}$ AVCD in RASopathies is usually partial, and may be associated with subaortic stenosis or aortic coarctation (Table 2) ${ }^{34,38,39}$ Structural abnormalities causing congenital subaortic stenosis include accessory fibrous tissue and/or anomalous insertion of the mitral valve and anomalous papillary muscle of the left ventricle. Anomalies of the mitral valve leaflets and of the subvalvular mitral apparatus in patients with NS and AVCD are similar to those found in patients with hypertrophic cardiomyopathy. ${ }^{40,41}$ This is not surprising, considering that myocardial disarray and cardiac hypertrophy are common features of patients with NS. An abnormal developmental mechanism of the left ventricular myocardium and of the mitral valve

should be considered in the pathogenesis of CHD in patients with NS. Cardiac jelly and extracellular matrix anomalies could account for CHDs in NS, and are likely responsible also for AVCD. ${ }^{2,42}$

PTPN11 gene mutations have been detected in patients with AVCD associated with

Table 1. Clinical characteristics of genetic disorders associated with atrioventricular canal defect.

\begin{tabular}{|c|c|c|}
\hline Syndrome & Genetic defect & Extracardiac features \\
\hline Down syndrome & Trisomy 21 & $\begin{array}{l}\text { Facial anomalies } \\
\text { Gastrointestinal malformations } \\
\text { Mental retardation }\end{array}$ \\
\hline Deletion 8p23 & Deletion 8p23 & $\begin{array}{l}\text { Facial anomalies } \\
\text { Microcephaly } \\
\text { Hypospadia } \\
\text { Mental retardation }\end{array}$ \\
\hline Deletion 3p25 & Deletion 3p25 & $\begin{array}{l}\text { Facial anomalies } \\
\text { Microcephaly } \\
\text { Cleft palate } \\
\text { Postaxial polydactyly } \\
\text { Gastrointestinal malformations } \\
\text { Renal anomalies }\end{array}$ \\
\hline Noonan syndrome & $\begin{array}{l}\text { PTPN11 and other RAS cascade } \\
\text { gene mutations }\end{array}$ & $\begin{array}{l}\text { Facial anomalies } \\
\text { Growth retardation } \\
\text { Skeletal defects } \\
\text { Cryptorchidism } \\
\text { Cognitive deficit }\end{array}$ \\
\hline CHARGE syndrome & CHD7 gene mutations & $\begin{array}{l}\text { Ocular coloboma } \\
\text { Choanal atresia } \\
\text { Ear anomalies } \\
\text { Deafness } \\
\text { Urogenital anomalies } \\
\text { Growth retardation }\end{array}$ \\
\hline 3C syndrome & Unknown & $\begin{array}{l}\text { Facial anomalies } \\
\text { Macrocephaly } \\
\text { Cerebellar malformation } \\
\text { Ocular coloboma } \\
\text { Mental retardation }\end{array}$ \\
\hline Ellis-van Creveld syndrome & $\begin{array}{l}\text { EVC gene mutations } \\
\text { EVC2 gene mutations }\end{array}$ & $\begin{array}{l}\text { Short-limb dwarfism } \\
\text { Short ribs } \\
\text { Postaxial polydactyly } \\
\text { Median cleft lip } \\
\text { Oral frenula }\end{array}$ \\
\hline Oral-facial digital syndromes & $\begin{array}{l}\text { OFD1: CXORF5 gene mutations } \\
\text { OFD6: TMEM216 gene mutations }\end{array}$ & $\begin{array}{l}\text { Hypertelorism } \\
\text { Tongue hamartoma } \\
\text { Oral frenula } \\
\text { Cleft palate } \\
\text { Postaxial and central polydactyly }\end{array}$ \\
\hline Bardet-Biedl syndrome & BBS1-BBS9 genes mutations & $\begin{array}{l}\text { Obesity } \\
\text { Retinitis pigmentosa } \\
\text { Postaxial polydactyly } \\
\text { Urogenital malformations } \\
\text { Cognitive deficit }\end{array}$ \\
\hline Smith-Lemli-Opitz syndrome & DHCR7 gene mutations & $\begin{array}{l}\text { Facial anomalies } \\
\text { Mental retardation } \\
\text { Microcephaly } \\
\text { Growth retardation } \\
\text { Feeding difficulties } \\
\text { Cleft palate } \\
\text { Postaxial polydactyly } \\
\text { Hypospadia } \\
\text { 2-3 toe syndactyly }\end{array}$ \\
\hline
\end{tabular}


Table 2. Cardiac characteristics of genetic syndromes associated with atrioventricular canal defect.

\begin{tabular}{|c|c|c|c|c|c|c|}
\hline Syndrome & $\begin{array}{c}\text { AVCD } \\
\text { (anatomic type) }\end{array}$ & $\begin{array}{l}\text { Associated CHDs } \\
\text { Left-sided obstruction }\end{array}$ & TOF & PVS & Common atrium & APVR \\
\hline Down syndrome & Complete & - & + & - & - & - \\
\hline Deletion 8p23 & Complete & - & + & + & + & - \\
\hline Deletion 3p25 & Partial/complete & - & - & - & + & - \\
\hline Noonan syndrome & Partial & + & - & + & - & - \\
\hline CHARGE syndrome & Complete & - & + & - & - & - \\
\hline 3C syndrome & Complete & - & + & - & - & - \\
\hline Ellis-van Creveld syndrome & Partial & - & - & - & + & - \\
\hline Oral-facial digital syndromes & Partial & - & - & - & + & - \\
\hline Bardet-Biedl syndrome & Partial & - & - & - & - & - \\
\hline Smith-Lemli-Opitz syndrome & Partial & - & - & - & - & + \\
\hline
\end{tabular}

RASopathies, in particular in patients with Noonan and LEOPARD syndromes. ${ }^{35,43}$ Two adjacent mutations in exon 2 (L43F and T42A) have been found in patients with AVCD, in association with $\mathrm{NS}^{43}$ and with apparently nonsyndromic AVCD. ${ }^{44}$

CHARGE and 3C (cranio-cerebello-cardiac) syndromes

CHD occurs in about $84 \%$ of patients with CHARGE syndrome. ${ }^{45}$ This disorder is characterized by ocular coloboma, choanal atresia, growth and mental retardation, genital anomalies, and hearing loss (Table 1). Mutations in the $C H D 7$ gene are detected in the majority of these patients. ${ }^{46,47}$ AVCD is the second most frequent CHD in CHARGE syndrome, often in association with tetralogy of Fallot (Table 2). ${ }^{48}$ AVCD with tetralogy of Fallot is also characteristic of 3C (cranio-cerebello-cardiac) syndrome, a genetic condition of unknown etiology displaying some overlap with CHARGE syndrome. The $3 \mathrm{C}$ syndrome is clinically defined by the association of cranial anomalies, cerebellar malformations (prevalently DandyWalker anomaly), and CHD. ${ }^{49-51}$

\section{Syndromes with polydactyly}

AVCD, particularly in association with common atrium, has been reported in several syndromes with postaxial polydactyly, including Ellis-van Creveld syndrome and other short ribpolydactlyly (SRP) disorders, oral-facial-digital syndromes, Bardet-Biedl syndrome, hydrolethalus syndrome, and Smith-Lemli-0pitz syndrome. ${ }^{52-54}$

The Ellis-van Creveld syndrome is an autosomal recessive disorder characterized by short-limb dwarfism, short ribs, postaxial polydactyly of hands and feet, ectodermal defects, and CHD (Table 1). This syndrome belongs to the group of SRP syndromes, together with Jeune syndrome and the I and IV subgroups of lethal SRP syndromes. ${ }^{55}$ In the 90 's a clinical overlap was established between SRP syn- dromes and oral-facial-digital (OFD) syndromes ${ }^{56,57}$ prompting the denomination of oral-facial-skeletal syndromes. ${ }^{57}$ The OFD syndromes are characterized by anomalies of the oral cavity (hamartoma of the tongue and gingival frenula), hypertelorism, cleft palate, hand and/or feet polydactyly, brachydactyly and clinodactyly (Table 1). At least 12 different types of OFD syndrome have been delineated based on clinical manifestations and inheritance patterns. AVCD is the commonest CHD in OFD syndrome type II. ${ }^{58}$ Examples of transitional phenotypes have been observed. ${ }^{59-61}$ The anatomic types of CHDs occurring in these syndromes also support the clinical overlap between these conditions. Published reports corroborate the association between these syndromes and heterotaxia heart defects..$^{52}$ In particular, the association of AVCD and common atrium found in patients with oral-facialskeletal syndrome is rare in the nonsyndromic patients, while is common in the oral-facialskeletal syndromes, and in heterotaxia syndrome with asplenia ${ }^{62}$ or polysplenia syndromes. ${ }^{63}$ The heterotaxia syndrome is characterized by an abnormal arrangement of the abdominal and thoracic organs with complex CHDs, including AVCD, common atrium, anomalous systemic and pulmonary venous drainage, persistent left superior vena cava with unroofed coronary sinus, and conotruncal defects. ${ }^{62,64}$ Complete situs inversus has been also found in patients with transitional phenotypes or lethal SRP syndromes. ${ }^{65-70}$ Interestingly, continuity in severity in the clinical spectrum of SRP syndromes has a counterpart also in the cardiac phenotype showing transition from AVCD and common atrium in Ellisvan Creveld syndrome to complete situs inversus in Jeune and lethal SRP syndromes.

AVCD, dextrocardia without structural cardiac defects and abdominal situs inversus are also found in Bardet-Biedl syndrome (BBS). ${ }^{52,54,71,72}$ This autosomal recessive disor- der is characterized by obesity, retinitis pigmentosa, postaxial polydactyly, genito-urinary malformations, cognitive impairment, and CHD. ${ }^{73}$ The phenotype of BBS overlaps with that of other disorders with postaxial polydactyly, including Meckel syndrome ${ }^{74}$ and Kaufmann-McKusick syndrome. ${ }^{75}$ BBS is a genetically heterogeneous disorder with at least 15 mutated loci and 9 cloned genes, whose proteins are involved in ciliary function regulation. ${ }^{76-79}$ The association between BBS and AVCD, which is considered a partial manifestation of heterotaxia, in a subset of these patients is of interest. In fact, while the BBS proteins do affect the ciliary function, the nodal cilium dysfunction is a known cause of left-right axis defects in vertebrates. ${ }^{80,81}$

Interestingly, failure of the left-axis specification with abnormal cardiac tube retaining a midline position or reversal of the heart loop have been demonstrated also in knock-out male mouse embryos lacking the OFD type 1 gene $($ Ofd 1$) .{ }^{82}$ Ultrastructural analysis in these experiments showed a lack of cilia in the embryonic node, and a specific role of the Ofd1 protein in cilium assembly through basal body dysfunction.

Ciliary anomalies have been demonstrated also in Ellis-van Creveld syndrome, ${ }^{83,84}$ and in some patients with severe forms of SRP syndromes. ${ }^{85}$ Using positional cloning, two genes ( $E V C$ and $E V C 2$ ) were found to be mutated in most of the patients with Ellis-van Creveld syndrome. ${ }^{86}$ Mutations in the WRD35 gene have been detected in patients with SRP syndrome. ${ }^{85}$ Experimental studies investigating molecular pathways and developmental processes perturbated in Ellis-van Creveld syndrome have demonstrated that $E V C$ gene is an intracellular component of the hedgehog signal transduction pathway that is required for normal transcriptional activation of the Indian hedgehog (Ihh) target genes. ${ }^{83}$ In particular, $E V C$ is a positive mediator of the Ihh-regulated 
bone-growth that localises at the base of chondrocyte cilia. ${ }^{83}$ Mouse models for the WDR35 gene mutations resulted in congenital abnormalities usually associated with defects in the Hedgehog signaling pathway. ${ }^{85}$

Following the observations in Smith-LemliOpitz (SLO) syndrome, perturbations of the different components of Sonic hedgehog (SHH) pathway have been associated with different developmental errors in patients manifesting partially overlapping features. ${ }^{53}$ SLO syndrome is an autosomal recessive disorder caused by an inborn error of cholesterol metabolism. Clinical manifestations include mental retardation, microcephaly, growth retardation with feeding difficulties, facial anomalies, cataract, cleft palate, hypospadia, postaxial polydactyly, 2-3 toe syndactyly, and CHD. ${ }^{87}$ Septal defects and AVCD are the most common CHDs in SLO syndrome, and AVCD is often associated with anomalous pulmonary venous return, the latter feature being also a cardiac manifestation of heterotaxia syndrome. ${ }^{88}$ Deficient 7-dehydrocholesterol- $\Delta-7$ reductase (DHCR7) activity results in reduced plasma and tissue cholesterol levels and elevated 7dehydrocholesterol concentrations. ${ }^{89}$ The human DHCR7 gene has beeen found to be responsible for the syndrome. ${ }^{90}$ Cholesterol has a critical role in the formation of normally active hedgehog proteins. ${ }^{91}$ Abnormal processing of the Hedgehog proteins secondary to abnormal cholesterol mechanism may have a role in the development of malformations in SLO syndrome. In particular, Sonic Hedgehog proteins are involved in left-right axis development, and the phenotype of Sonic Hedgehog (-/-) mice shows CHDs in the setting of heterotaxia and left pulmonary isomerism. ${ }^{92-94}$ Accordingly, the association of AVCD and anomalous pulmonary venous return as partial manifestation of heterotaxia in SLO syndrome is not surprising.

The clinical spectrum of ciliopathies linked to polydactyly and/or cardiac laterality defects has been further expanded, including hydrolethalus and acrocallosal syndromes, caused by mutations in KIF7, a gene belonging to the Hedgehog pathway through the regulation of GLI targets, ${ }^{95}$ and oculofaciocardiodental syndrome, resulting from mutations in BCOR. ${ }^{96,97}$

\section{Conclusions}

AVCD displays a wide anatomic variability, likely reflecting genetic heterogeneity and association with distinct genetic disorders. Chromosome syndromes more frequently associated with AVCD include Down syndrome, deletion 8p23 and deletion 3p25, while mendelian syndromes with AVCD are Noonan syndrome and related RASopathies, syndromes with polydactyly, CHARGE and 3C (cranio-cerebello-cardiac) syndrome. The complete form of AVCD is prevailing in patients with chromosomal imbalances. Additional cardiac defects are found in patients with syndromes different from Down syndrome. Left-sided obstructive lesions are mainly found in patients with Rasopathies. Patients with deletion 8p23 may be affected by AVCD with tetralogy of Fallot or with pulmonary valve stenosis. Tetralogy of Fallot is the only additional cardiac defect detected in patients with Down syndrome and AVCD. On the other hand, the association of AVCD and tetralogy of Fallot is also characteristic of CHARGE and 3C syndromes. CHDs in the spectrum of heterotaxia syndrome, including common atrium and anomalous pulmonary venous return, are diagnosed in patients with AVCD and polydactyly syndromes (Ellis-van Creveld, short rib polydactyly, oral-facial-digital, Bardet-Biedl, SL0 syndromes). The initial clinical observation of phenotypical similarities between the anatomy of AVCD and heterotaxia in syndromes with polydactyly has been supported by experimental studies in transgenic mice, and the suggested involvement of the Sonic Hedgehog pathway in syndromes with postaxial polydactyly and heterotaxia has been confirmed by the detection of ciliary dysfunction in several disorders with polydactyly.

Anatomic differences in AVCD are probably related to distinct genetic causes. The study of peculiar cardiovascular defects associated with extracardiac anomalies occurring in the different syndromes may improve the assessment of prognostic factors and the understanding of genotype-prognostic correlates. ${ }^{98}$

\section{References}

1. Perry LW, Neill CA, Ferencz C, et al. Infants with congenital heart disease: the cases. In: Ferencz C, Rubin JD, Loffredo CA, Magee CA, editors. Pediatric Cardiology. Epidemiology of congenital heart disease. The Baltimore-Washington Infant Study 1981-1989. Mount Kisco, New York: Futura Publishing Company, Inc; 1993. pp. 33-62.

2. Clark EB. Mechanism in the pathogenesis of congenital heart defects. In: Pierpont ME, Moller J. The Genetics of Cardio vascular Disease. Boston, MA: MartinusNijoff;1986. pp.3-11.

3. Ferencz C, Loffredo CA, Correa-Villasenor A, Wilson PD (eds). Genetic and environmental risk factors of major cardiovascular malformations. The Baltimore-Washington Infant Study 1981-1989. Armonk, New York: Futura Publishing Company Inc; 1997.

4. Digilio MC, Marino B, Toscano A, et al. Atrioventricular canal defect without
Down syndrome: a heterogeneous malformation. Am J Med Genet 1999;85:140-6.

5. Hunter AGW. Down syndrome. In: Cassidy SB, Allanson JE, (eds). Management of genetic syndromes. Hoboken, New Jersey: John Wiley \& Sons Inc; 2005. pp. 191-210.

6. De Biase L, Di Ciommo V, Ballerini L, et al. Prevalence of left-sided obstructive lesions in patients with atrioventricular canal without Down's syndrome. J Thorac Cardiovasc Surg 1986;91:467-9.

7. Marino B. Left-sided cardiac obstruction in patients with Down sindrome. J Pediatr 1989;115:834-5.

8. Marino B, Vairo U, Corno A, et al. Atrio ventricular canal in Down syndrome. Prevalence of associated cardiac malformations compared with patients without Down syndrome. Am J Dis Child 1990;144: $1120-2$.

9. Marino B. Patterns of congenital heart disease and associated cardiac anomalies in children with Down syndrome. In: Marino B, Pueschel SM (eds). Heart Disease in Persons with Down Syndrome. Baltimore: Brookes Publishing; 1996. pp. 33-140.

10. Carmi R, Boughman JA, Ferencz C. Endocardial cushion defect: further studies of "isolated" versus "syndromic" occurrence. Am J Med Genet 1992;43:569-75.

11. Formigari R, Di Donato RM, Gargiulo G, et al. Better surgical prognosis for patients with complete atrioventricular septal defect and Down's syndrome. Ann Thorac Surg 2004;78:666-72.

12. Korenberg JR, Barlow GM, Chen X-N, et al. Down syndrome congenital heart disease: narrowed region and DSCAM as a candidate gene. In: Clark EB, Nakazawa M, Takao A (eds). Etiology and morphogenesis of congenital heart disease: Twenty years of progress in genetics and developmental biology. Armonk, New York: Futura Publishing Co, Inc; 2000. pp. 365-370.

13. Jongewaard IN, Lauer RM, Behrendt DA, et al. Beta 1 integrin activation mediates adhesive differences between trisomy 21 on non-trisomic fibroblasts on type VI collagen. Am J Med Genet 2002;109:298-305.

14. Arron JR, Winslow MM, Polleri A, et al. NFAT dysregulation by increased dosage of DSCR1 and DYRK1A on chromosome 21. Nature 2006;441:595-600.

15. Brocker-Vriends AH, Mooji PD, Van Bell F, et al. Monosomy 8p: an easily overlooked syndrome. J Med Genet 1986;23:153-4.

16. Hutchinson R, Wilson M, Voullaire L. Distal 8p deletion (8p23.1----8pter): a common deletion? J Med Genet 1992;29:40711.

17. Wu B-L, Schneider GH, Sabatino DE, et al. Distal 8p deletion (8)(p23.1): an easily missed chromosomal abnormality that may be associated with congenital heart 
defect and mental retardation. Am J Med Genet 1996;62:77-83.

18. Digilio MC, Marino B, Guccione P, et al. Deletion 8p sindrome. Am J Med Genet 1998;75:534-6.

19. Paez MT, Yamamoto T, Hayashi K, et al. Two patients with atypical interstitial deletions of 8p23.1: mapping of phenotypical traits. Am J Med Genet 2008;146A:1158-65.

20. Marino B, Reale A, Giannotti A, et al. Nonrandom association of atrioventricular canal and del (8p) syndrome. Am J Med Genet 1992;42:424-7.

21. Digilio MC, Giannotti A, Marino B, Dallapiccola B. Atrioventricular canal and 8p- syndrome. Am J Med Genet 1993;47: 437-8.

22. Devriendt K, Matthijs G, Van Dael R, et al. Delineation of the critical deletion region for congenital heart defects, on chromosome 8p23.1. Am J Hum Genet 1999;64:1119-26.

23. Pehlivan T, Pober BR, Brueckner M, et al. GATA4 haploinsufficiency in patients with interstitial deletion of chromosome region 8p23.1 and congenital heart disease. Am J Med Genet 1999;83:201-6.

24. Giglio S, Graw SL, Gimelli G, et al. Deletion of a 5-cM region at chromosome 8p23 is associated with a spectrum of congenital heart defects. Circulation 2000;102:432-7.

25. Phipps ME, Latif F, Prowse A, et al. Molecular genetic analysis of the 3p- syndrome. Hum Molec Genet 1994;3:903-8.

26. Drumheller T, McGillivray C, Behrner D, et al. Precise localization of 3p25 breakpoints in four patients with the 3p- syndrome. $\mathrm{J}$ Med Genet 1996;33:842-7.

27. Green EK, Priestley MD, Waters J, et al. Detailed mapping of a congenital heart disease gene in chromosome $3 \mathrm{p} 25$. J Med Genet 2000;37:581-7.

28. Ramer JC, Ladda RL, Franckel C. Two infants with del(3)(p25pter) and a review of previously reported cases. Am J Med Genet 1989;33:108-12.

29. Rupp PA, Fouad GT, Egelston CA, et al. Identification, genomic organization and mRNA expression of CRELD1, the founding member of a unique family of matricellular proteins. Gene 2002;293:47-57.

30. Robinson SW, Morris CD, Goldmuntz E, et al. Missense mutations in CRELD1 are associated with cardiac atrioventricular septal defects. Am J Hum Genet 2003;72: 1047-52.

31. Schubbert S, Bollag G, Shannon K. Deregulated Ras signaling in developmental disorders: new tricks for an old dog. Curr Opinion Genet Dev 2007;17:15-22.

32. Tidyman WE, Rauen KA. The RASopathies: developmental syndromes of Ras/MAPK pathway dysregulation. Curr Opin Genet Dev 2009;19:230-6.
33. Tartaglia M, Zampino G, Gelb BD. Noonan syndrome: clinical aspects and molecular pathogenesis. Molec Syndromol 2010;1:226.

34. Marino B, Digilio MC, Toscano A, et al. Congenital heart diseases in children with Noonan syndrome: An expanded cardiac spectrum with high prevalence of atrioventricular canal. J Pediatr 1999;135:7036.

35. Sarkozy A, Conti E, Seripa D, et al. Correlation between PTPN11 gene mutations and congenital heart defects in Noonan and LEOPARD syndromes. J Med Genet 2003;40:704-8.

36. Digilio MC, Conti E, Sarkozy A, et al. Grouping of multiple-lentigines/LEOPARD and Noonan syndromes on the PTPN11 gene. Am J Hum Genet 2002;71:389-94.

37. Sarkozy A, Conti E, Digilio MC, et al. Clinical and molecular analysis of 30 patients with multiple lentigines LEOPARD sindrome. J Med Genet 2004;41:e68.

38. Marino B, Gagliardi MG, Digilio MC, et al. Noonan sindrome: structural abnormalities of the mitral valve causing subaortic obstruction. Eur J Pediatr 1995;154:94952.

39. Gow RM, Freedom RM, Williams WG, et al. Coarctation of the aorta or subaortic stenosis with atrioventricular septal defect. Am J Cardiol 1984;53:1421-8.

40. Klues HG, Roberts WC, Maron BJ. Anomalous insertion of the papillary muscle directly into anterior mitral leaflet in hypertrophic cardiomyopathy. Significance in producing left ventricular outflow obstruction. Circulation 1991;84: 1188-97.

41. Klues HG, Maron BJ, Dollar AL, Roberts WC. Diversity of structural mitral valve alterations in hypertrophic cardiomyopathy. Circulation 1992;85:1651-60.

42. Amman G, Sherman FS. Myocardial dysgenesis with persistent sinusoids in a neonate with Noonan's phenotype. Pediatr Pathol 1992;12:83-92.

43. Sarkozy A, Lepri F, Marino B, et al. Additional evidence that PTPN11 mutations play only a minor role in the pathogenesis of non-syndromic atrioventricular canal defect. Am J Med Genet 2006;140: 1970-2.

44. Weismann CG, Hager A, Kaemmerer H, et al. PTPN11 mutations play a minor role in isolated congenital heart disease. Am J Med Genet 2005;136A:146-51.

45. Trip J, van Stuijvenberg M, Dikkers FG, Pijnenburg MW. Unilateral CHARGE association. Eur J Pediatr 2002;161:78-80.

46. Vissers LELM, van Ravenswaaij CM, Admiral R, et al. Mutations in a new member of the chromodomain gene family cause CHARGE syndrome. Nat Genet 2004; 36:955-7.
47. Lalani SR, Safiullah AM, Fernbach SD, et al. Spectrum of CHD7 mutations in 110 individuals with CHARGE syndrome and genotype-phenotype correlation. Am J Hum Genet 2006;78:303-14.

48. Wyse RK, al-Mahdawi S, Burn J, Blake K. Congenital heart disease in CHARGE association. Pediatr Cardiol 1993;14:75-81.

49. Ritscher D, Schinzel A, Boltshauser E, et al. Dandy-Walker(like) malformation, atrio-ventricular septal defect and a similar pattern of minor anomalies in 2 sisters: a new syndrome? Am J Med Genet 1987;26: 481-91.

50. Digilio MC, Marino B, Giannotti A, et al. Atrioventricular canal and 3C (craniocerebello-cardiac) syndrome. Am J Med Genet 1995;58:97-8.

51. Vergara P, Digilio MC, de Zorzi A, et al. Genetic heterogeneity and phenotypic anomalies in children with atrioventricular canal and tetralogy of Fallot. Clin Dysmorphol 2006;15:65-70.

52. Digilio MC, Marino B, Ammirati A, et al. Cardiac malformations in patients with oral-facial-skeletal syndromes: clinical similarities with heterotaxia. Am J Med Genet 1999;84:350-6.

53. Digilio MC, Marino B, Giannotti A, et al. Specific congenital heart defects in RSH/Smith-Lemli-Opitz sindrome: postulated involvement of the sonic hedgehog pathway in syndromes with postaxial polydactyly or heterotaxia. Birth Defects Res A Clin Mol Teratol 2003;67:149-53.

54. Digilio MC, Dallapiccola B, Marino B. Atrioventricular canal defect in BardetBiedl syndrome: clinical evidence supporting the link between atrioventricular canal defect and polydactyly syndromes with ciliary dysfunction. Genet Med 2006;8:536-8.

55. Beighton P, Giedion A, Gorlin R, et al. International classification of osteochondrodysplasias. International Working Group on Constitutional Diseases of Bone. Am J Med Genet 1992;44:223-9.

56. Franceschini P, Guala A, Vardeu MP, et al. Short rib-dysplasia group (with/without polydactyly): report of a patient suggesting the existence of a continuous spectrum. Am J Med Genet 1995;59:359-64.

57. Neri G, Guerrieri F, Genuardi M. Oralfacial-skeletal syndromes. Am J Med Genet 1995;59:365-8.

58. Digilio MC, Marino B, Giannotti A, Dallapiccola B. Orocardiodigital sindrome: an oral-facial-digital type II-variant associated with atrioventricular canal. J Med Genet 1996;33:416-8.

59. Hingorani SR, Pagon RA, Shepard TH, Kapur RP. Twin fetuses with abnormalities that overlap with three midline malformation complexes. Am J Med Genet 1991;41: 230-5. 
60. Muenke M, Ruchelli ED, Rorke LB, et al. On lumping and splitting: a fetus with clinical findings of the oral-facial-digital syndrome type VI, the hydrolethalus syndrome, and the Pallister-Hall syndrome. Am J Med Genet 1991;41:548-56.

61. Yapar EG, Ekici E, Aydogdu T, et al. Diagnostic problems in a case with mucometrocolpos, polydactyly, congenital heart disease, and skeletal dysplasia. Am J Med Genet 1996;66:343-6.

62. Phoon CK, Neill CA. Asplenia syndrome: insight into embryology through an analysis of cardiac and extracardiac anomalies. Am J Cardiol 1994;73:581-7.

63. Peoples WM, Moller JH, Edwards JE. Polysplenia: a review of 146 cases. Pediatr Cardiol 1983;4:129-38.

64. Webber SA, Taylor GP, Colwell K, et al. Extracardiac malformations in asplenia syndrome. Cardio Young 1992;2:136-40.

65. Belloni C, Beluffi G. Short rib-polydactyly syndrome, type Verma-Naumoff. Rofo 1981;134:431-5.

66. Fraser FC, Jequier S, Chen MF. Chondrodysplasia, situs inversus totalis, cleft epiglottis and larynx, hexadactyly of hands and feet, pancreatic cystic dysplasia, renal dysplasia/absence, micropenis and ambiguous genitalia, imperforate anus. Am J Med Genet 1989;34:401-5.

67. Brueton LA, Dillon MJ, Winter RM. Ellisvan Creveld syndrome, Jeune syndrome, and renal-hepatic-pancreatic dysplasia: separate entities or disease spectrum? J Med Genet 1990;27:252-5.

68. Tsai YC, Chang JM, Changchien CC, et al. Unusual short rib-polydactyly syndrome. Am J Med Genet 1992;44:31-6.

69. de Sierra TM, Ashmead G, Bilenker R. Prenatal diagnosis of short rib (polydactyly) syndrome with situs inversus. Am J Med Genet 1992;44:555-7.

70. Urioste M, Martinez-Frias ML, Bermelo E, et al. Short-rib-polydactyly sindrome and pericentric inversion of chromosome 4 . Am J Med Genet 1994;49:94-7.

71. Slavotinek AM, Biesecker LG. Phenotypic overlap of McKusick-Kaufman syndrome with Bardet-Biedl syndrome: a literature review. Am J Med Genet 2000;95:208-15.

72. Lorda-Sanchez I, Ayuso C, Ibanez A. Situs inversus and Hirschprung disease: Two uncommon manifestations in BardetBiedl syndrome. Am J Med Genet 2000;90: 80-1.

73. Beals PL, Elcioglu N, Woolf AS, et al. New criteria for improved diagnosis of Bardet-
Biedl syndrome: results of a population survey. J Med Genet 1999;36:437-46.

74. Karmpous-Benailly H, Martinovic J, Gubler $\mathrm{M}-\mathrm{C}$, et al. Antenatal presentation of Bardet-Biedl syndrome may mimic Meckel syndrome. Am J Hum Genet 2005;76:493504.

75. Slavotinek AM, Biesecker LG. Phenotypic overlap of McKusick-Kaufman syndrome with Bardet-Biedl syndrome: a literature review. Am J Med Genet 2000;95:208-15.

76. Ansley SJ, Badano JL, Blacque OE, et al. Basal body dysfunction is a likely cause of pleiotropic Bardet-Biedl syndrome. Nature 2003;425:628-33.

77. Kim JC, Badano JL, Sibold S, et al. The Bardet-Biedl protein BBS4 targets cargo to the pericentriolar region and is required for microtubule anchoring and cell cycle progression. Nat Genet 2004;36:462-70.

78. Fan Y, Esmail MA, Ansley SJ, et al. Mutations in a member of the Ras superfamily of small GTP-binding proteins causes Bardet-Biedl syndrome. Nat Genet 2004;36:989-93.

79. Li JB, Gerdes JM, Haycraft CJ, et al. Comparative genomics identifies a flagellar and basal body proteome that includes the BBS5 human disease gene. Cell 2004; 117:541-52.

80. Supp DM, Wite DP, Potter SS, Brueckner M. Mutation in an axonemal dynein affects left-right asymmetry in inversus viscerum mice. Nature 1997;389:963-6.

81. Okada Y, Nonaka S, Tanaka Y, et al. Abnormal nodal flow precedes situs inversus in iv and inv mice. Mol Cell 1999;4:45968.

82. Ferrante MI, Zullo A, Barra A, et al. Oralfacial-digital type I protein is required for primary cilia formation and left-right axis specification. Nat Genet 2006;38:112-7.

83. Ruiz-Perez VL, Blair HJ, Rodriguez-Andres $\mathrm{ME}$, et al. EVC is a positive mediator of Ihh-regulated bone growth that localises at the base of chondrocyte cilia. Development 2007;134:2903-12.

84. Ruiz-Perez VL, Goodship JA. Ellis-van Creveld syndrome and Weyers acrodental dysostosis are caused by cilia-mediated diminished response to hedgehog ligands. Am J Med Genet 2009;151C:341-51.

85. Mill P, Lockhart PJ, Fitzpatrick E, et al. Human and mouse mutations in WDR35 cause short-rib polydactyly syndromes due to abnormal ciliogenesis. Am J Hum Genet 2011;88:508-15.

86. Ruiz-Perez V, Tompson S, Blair H, et al.
Mutations in two nonhomologous genes in a head-to-head configuration cause Ellisvan Creveld syndrome. Am J Hum Genet 2003;72:728-32.

87. Kelley RI, Hennekam RC. The SmithLemli-Opitz syndrome. J Med Genet 37: 321-35.

88. Lin AE, Ardinger HH, Ardinger RH Jr, et al. Cardiovascular malformations in SmithLemli-Opitz syndrome. Am J Med Genet 1997;68:270-8.

89. Shefer S, Salen G, Batta AK, et al. Markedly inhibited 7-dehydrocholesterol-delta7reductase activity in liver microsomes from Smith-Lemli-Opitz homozygotes. J Clin Invest 1995;96:1779-85.

90. Moebius FF, Fitzky BU, Lee JN, et al. Molecular cloning and expression of the human delta7-sterol reductase. Proc Natl Acad Sci USA 1998;95:1899-902.

91. Chamoun Z, Mann RK, Nellen D, et al. Skinny hedgehog, an acyltransferase required for palmitolation and activity of the hedgehog signal. Science 2001;293: 1080-2084.

92. Chiang C, Litingtung Y, Lee E, et al. Cyclopia and defective axial patterning in mice lacking Sonic hedgehog gene function. Nature 1996;383-407-13.

93. Meyers EN, Martin GR. Differences in leftright axis pathways in mouse and chick: functions in FGF8 and SHH. Science 1999;285:403-6.

94. Tsukui T, Capdevila J, Tamura K, et al. Multiple left-right asymmetry defects in Shh(-/-) mutant mice unveil a convergence of the shh and retinoic acid pathways in the control of Lefty-1. Proc Natl Acad Sci USA 1999;96:11376-81.

95. Putoux A, Thomas S, Coene KL, et al. KIF7 mutations cause fetal hydrolethalus and acrocallosal syndromes. Nat Genet 2011; 43:601-6.

96. Ng D, Thakker N, Corcoran CM, et al. Oculofaciocardiodental and Lenz microphthalmia syndromes result from distinct classes of mutations in BCOR. Nat Genet 2004;36:411-6.

97. Hilton EN, Manson FD, Urquhart JE, et al. Left-sided expression of the BCL- 6 corepressor, BCOR, is required for vertebrate laterality determination. Hum Mol Genet 2007;16:1773-82.

98. Formigari R, Michielon G, Digilio MC, et al. Genetic syndromes and congenital heart defects: how is surgical management affected? Eur J Cardiothorac Surg 2009;35:606-14. 